\section{Community-based Mangrove Forest Management in Association with Sustainable Tourism in Puerto Princesa City of the Philippines}

\section{Dimithri Devinda Jayagoda ${ }^{a^{*}}$}

${ }^{a}$ Ritsumeikan Asia Pacific University, 1-1 Jumonjibaru, Beppu, Oita 874-8577 Japan

Received: November 26, 2013/ Accepted: September 28, 2015

\begin{abstract}
Puerto Princesa City in Palawan, the Philippines, is known as the "City in the Forest." Former Mayor Edward Hagedorn's vision was "To see Puerto Princesa as a model city in sustainable development." The objective of this study was to describe, using selected case studies, how community-based sustainable tourism is effectively practiced while protecting and rehabilitating mangroves in Puerto Princesa City. In this study, both qualitative and quantitative approaches were used as a mixed methodology. Primary and sometimes secondary data were gathered through interviews, case studies, observation, photography, focus groups, and surveys. Photography was used as a method to document qualitative information. Participatory research methods were used throughout the study, while observations and video recording were used to document findings. Three Community Based Sustainable Tourism (CBST) case studies were selected and discussed, as follows: "San Carlos Floating Restaurant," "Sabang Mangrove Paddleboat Tour" and "Firefly Watch in Iwahig Mangrove Forest." In addition to the case studies of these attractions, the annually conducted "Love Affair with Nature" mangrove planting project is also discussed in brief. A study conducted by the Palawan Council for Sustainable Development (PCSD) in 2005 shows that mangrove forest cover in Puerto Princesa has increased compared in 1992.
\end{abstract}

Keywords: Community involvement; Sustainable tourism; Mangroves; Sustainable development

\begin{tabular}{|rl|}
\hline Abbreviations: & \\
\hline CBST: & Community Based Sustainable Tourism \\
PCSD: & Palawan Council for Sustainable Development \\
DENR: & $\begin{array}{l}\text { Department of Environment and Natural } \\
\text { Resources }\end{array}$ \\
\hline
\end{tabular}

* Corresponding Author

E-mail: mostlyibelieveinmyself@gmail.com

\section{Introduction}

Community Based Sustainable Tourism activities are common occurrences in the city of Puerto Princesa in Palawan, the Philippines, also known as the "City in the Forest." Honorable Mayor Edward Hagedorn initiated several projects to accomplish his vision of "To see Puerto Princesa as a model city in sustainable development." All these projects are given high emphasis to develop community capacity while protecting the environment. Puerto Princesa, with a land area of 253,982 hectares, boasts a forest cover of about 73 percent. The city is home for a population of 225,955 (City Information, 2007). Not only the local community is keen about alternative livelihood opportunities, but also they are very aware of the sustainable tourism potential of the city, while at the same time being fully committed in protecting the environment. Due to the genuine efforts of the community and reliable leadership, Puerto Princesa City was declared as the first Carbon Neutral city by the Association of Southeast Asian Nations (ASEAN). Puerto Princesa is not only carbon neutral, but also a significantly carbon negative city. Before sharing the success story of Puerto Princesa, it is essential to investigate the current global and country (Philippines) status of mangrove forests.

\subsection{Dwindling Mangroves around the world}

World Atlas of Mangroves, (2010) defines mangroves as "trees or large shrubs, including ferns and palms, which normally grow in or adjacent to the intertidal zone and which have developed a special adaptation in order to survive in this environment." Malena, (2000) says, "Mangroves are a community of intertidal plants including all species of trees, shrubs, vines and herbs found on coasts, swamps, or border of rivers." Mangroves are ranging in northern latitudes as high as 32 degrees, even though they are quite unique within 25 degrees north and south of the equator (Maltby, 1986). Unfortunately in some parts of the world, tourism industry has seen this resource as an obstacle as Mangrove Action Project mentioned "Mangrove forests are often seen as obstructions to one's view from a bay-side hotel or obstacles to easy beach access. They are frequently looked at as mosquitoinfested muddy swamps holding back progress and hindering tourism development. They may be vilified by developers, lending agencies, and governments alike, and allowed to be rapidly cleared without thorough environmental impact studies in order to make way for the promise of great profits from industrial-scale developments" (MAP, 2013). Mangroves cover an area of between 190,000 and 240,000 square kilometres globally and count for onequarter of the world's tropical and sub-tropical coastlines (Kelleher, 1995). The World Atlas of Mangroves, (2010) suggests that the total area of remaining mangroves in this millennium is only 150,00o square kilometres. Based on available national statistics, these calculations are given to show current availability, indicating mangroves to be a rare global habitat. They currently make up less than 1 percent of tropical forests worldwide and less than 0.4 percent of the global total forest $(39,520,000$ square kilometres) (FAO, 2006).

Increasing population pressure in the coastal areas and overharvesting of timber and other wood products are main factors causing destruction of mangrove forests. In recent years, a more significant cause appears to be the demand for land by key primary sector economic development activities such as mining, conversion to salt ponds, shrimp ponds, agricultural and 
aquaculture expansion (Barbier, 2003). From 1989, shrimp farming has increased over 400 percent in tropical countries and world shrimp production increased from 5 percent in 1982 to over 30 percent by 1996 (Anderson and Fong, 1997). Naylor et al., (2000) states that farmed fish and shellfish in the coastal zone have more than doubled in the past 15 years and there is a huge increase in global demand. As shown in Figure 1, during the period 1980 to 2005, there was a dramatic loss in mangrove forest in every region except for Australia. South East Asia, North and Central America, Pacific Ocean and East Asia shows the highest decrease, more than 20 percent in 25 years. Duke et al., (2007) estimated that the decline is one to two percent while Valiela et al., (2001) said it to be 2.07 percent per year. These estimates are significantly higher than the FAO estimates. Rate of mangrove loss is three to four times higher than overall global forest loss, which was estimated at 0.22 percent per year in the 1990's, dropping to 0.18 percent per year in the five years to 2005 (FAO, 2006). Countries in East Asia, South East Asia and the Pacific have the highest annual rate of decline, amounting to more than one percent as shown in Figure 1. "The world mangrove experts are of the opinion that the long-term survival of mangroves is at great risk due to fragmentation of the habitats and that the services offered by the mangroves may likely be totally lost within 100 years" (Duke et al., 2007).

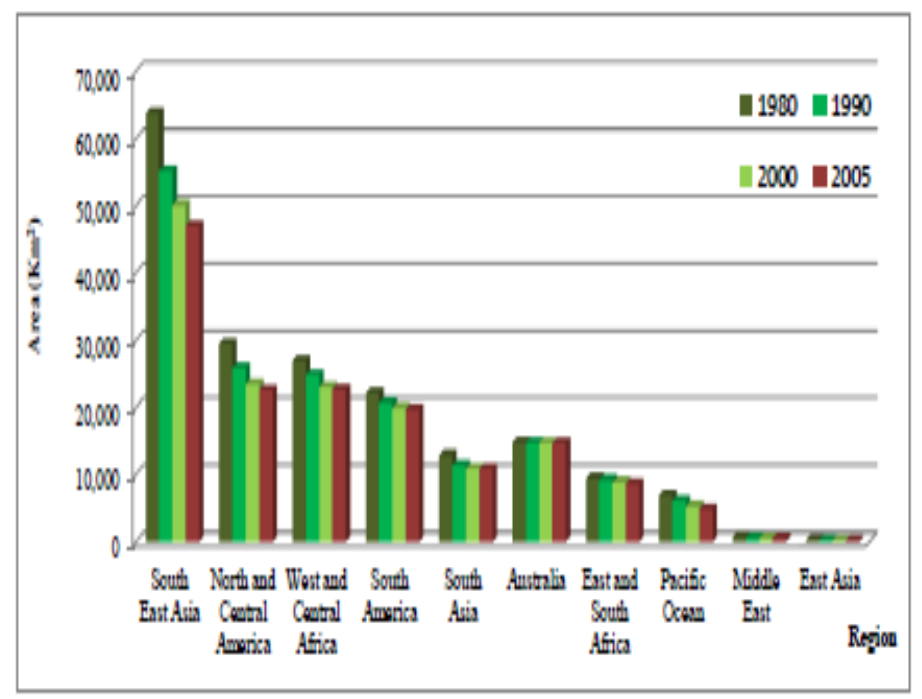

Figure 1 Decline in Mangrove by Region Between 1980- 2005

(Source: Estimations based on FAO, 2007 data)

\subsection{Status of the declining mangroves in the Philippines}

Philippine mangrove forest area was estimated around 450,0oo hectares in 1920. This area has reduced to less than 150,000 hectares as shown on Figure 2, distributed among 22 percent in Palawan, 32 percent in Mindanao, and 23 percent in Eastern Visayas and Bohol (DENR 2011, interview). Heavy conversion to fishponds and salt beds, cutting of trees for firewood and other domestic uses, and reclamation for industrial or other development purposes are the main reasons for this drastic loss. Cheryl et al., (2005) mentioned that the mangroves in the Philippines were 500,00o hectares in the early 1900's and had been reduced to 117,700 hectares by 1993 spread over 18,0oo kilometres of shoreline. There is a record of mangrove depletion at a rate of 3,700 hectares per year from 1980 to 1991 (DENR, 2003). This was especially due to conversion to fishponds. Old growth mangrove areas are reduced to less than 20,00o hectares, about 65 percent of which were in Palawan and the remaining in Zamboanga del Sur (Cheryl et al., 2005).

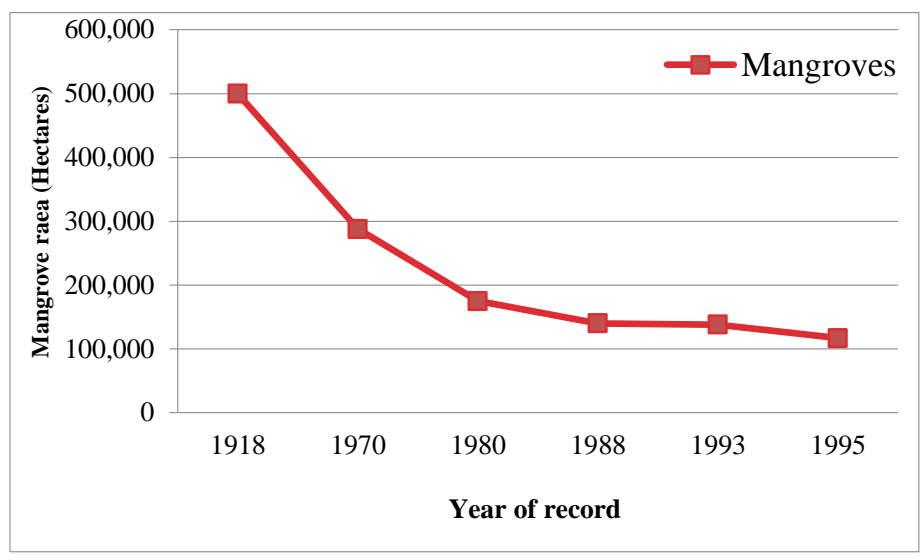

Figure 2 Declining of Mangrove Resources in the Philippines

(Source: Modifications based on DENR Statistics 1998)

Mangroves in the Philippines have changed substantially over the last 100 years. Huge quantities of mangroves have been lost and the remaining areas were degraded to some extent. According to Primavera, (2000) 99.8 percent of mangroves in Manila Bay in 1951 had vanished by the year 1994. Further, in Visayan Islands the losses were dramatic, with 95 percent of mangroves lost from 1951 to 1994. Between 1968 and 1983, almost half of the total national mangrove areas were lost, amounting to 237,00o hectares of mangrove (Fernandez, 1978). According to the Research and Development Extension Framework, (2007-2010), mangroves have degraded continuously and about 25 percent of the original mangrove areas have been converted into fishponds, with an average rate of 5,00o hectares per year in the 1970's and early l980's.

\subsection{Island Tourism}

Island tourism shares various characteristics with standard tourism. Recently, much emphasis has been given to ecotourism, sustainable tourism and community-based tourism in island destinations. It is very difficult to define an island. The most usual definition is that it is a "land surrounded by water on all sides," but it is not used by every organization and throughout the academia. For some, how far it is from the mainland, how big it is in terms of land area, whether people live on it or not, and if there is a capital city in the island or not, are some of the concerns to desire whether it is an island or not (Graci and Dodds, 2010). Sonya and Rachel also note, "People travel to obtain the island experience and visit communities that are isolated, display rich and diverse cultures, unique environmental attributes and exotic species. Island communities have varied languages, histories, societies, governance forms and livelihoods." Dimitrios et al., (2007) state, "Tourism has been instrumental in the development of peripheral, remote, and insular regions, like islands, which are commonly characterised by peripherally, isolations, fragility, scarcity of resources, limited labour force and transportation cost, all being competitive disadvantages." Dodds and McElroy, (2008) observe, "Islands, by focusing exclusively on tourism as their main source of foreign exchange, without long term planning for sustainable development, are potentially facing crises equal if not worse than their agricultural demise." Fishing and agriculture have become 
major income generation activities among island communities and now they are introducing tourism as an alternative livelihood (Lockhart, 1997), becoming their main income and contributing heavily to economic development, hence the multiplier effect is higher in the tourism industry.

\subsection{Sustainable Tourism}

Sustainable tourism associates with three pillars of sustainable development. Economic, environmental and social cultural aspects of tourism are related to sustainable development according to Butler, (1993). He defines sustainable tourism development as "tourism which is developed and maintained in an area (community, environment) in such a manner and such a scale that it remains viable over an indefinite period and does not degrade or alter the environment (human and physical) in which it exists to such a degree that it prohibits successful development and wellbeing of other activities and programs." The World Tourism Organization (WTO, 2005) gives the full definition of sustainable tourism as "tourism that takes full account of its current and future economic, social and environmental impacts, addressing the needs of visitors, the industry, the environment and host communities."

The need for sustainable tourism arises from various issues incorporated in most of the destinations, including islands. Graci and Dodds (2010) gave the following as common issues faced by destinations (also mentioned by Aggrawal 2002, Dodds 2008, Filho 1996, Garci 2010, Harrison 2003, UNEP 1996, UNCSD 1999, Wheeler 1993 and Wilkinson 1989): dependency of a host community's economy on tourism; competition; leakage; government debt to finance development; loss of habitat areas and resources due to development and pollution; decline in biodiversity of species and ecosystems; erosion; loss of natural and architectural heritage in the face of rapid expansion; decline in quantity and quality of water resources; sea, land, noise and air pollution; increased congestion and strains of infrastructure; rapid decline of traditional pursuits by locals because of a change in habitats due to tourism; excessive use of natural resources; encroachment of buildings, facilities and roads close to coastline; crowding and pressure on services; displacement of local population; inflation; foreign customs and expectations creating conflicts.

\section{Research methodology}

The main objective of this study was to describe, through the use of selected case studies, how community-based sustainable tourism is best practiced while protecting and rehabilitating mangroves in Puerto Princesa City of Palawan. In order to achieve this objective, several questions were answered using a mixed research methodology. How do community stakeholders and their leadership contribute to the implementation and development of community-based sustainable tourism and mangrove planting projects in the city? How does community involvement result in the continuation of ongoing social, environmental and economic development projects? How did the community capacity and awareness about environment protection increased as long-term benefits of ongoing projects? How community-based projects play an important role in achieving island sustainability?

Both qualitative and quantitative approaches were used in this study as a mixed methodology. Data were gathered from both secondary and primary sources. Data gathering techniques used in this study were desk research, interviews, case studies, observations, photography, focus groups, and surveys. The interviews were conducted at three different stages. Policy makers, including a former city mayor, the current city mayor, high ranked city hall and city environment office staff were interviewed individually. Focus group discussions and individual interviews were conducted with faculty members of the Palawan State University, Palawan Council for Sustainable Development (PCSD), City Information, and City Planning and City Agriculture offices. Three different questionnaires were used to interview people at different stages. Informal discussions and interviews were conducted among community leaders, university students, fishermen and participants at the "Love Affair with Nature" in 2011 and 2013. The author participated in "Love affair with Nature," annual mangrove planting project in 2011 and 2013 and visited the planting sites and planning offices in 2010, 2011 and 2013. Strict observations were made during these visits, and photography was used to record qualitative findings. Also, observations and case studies were conducted in three mangrove-based ecotourism sites to gather more information and opinions of local citizens and related stakeholders. Notes were taken during informal discussions. Participatory research methods were used throughout the study, while observations and video recording were used to document findings.

\section{Case Studies of Community Based Sustainable Tourism}

It is vital to define "community" before describing communitybased sustainable tourism case studies. Macqueen et al., (2001) defines community as "a group of people with diverse characteristics who are linked by social ties, share common perspectives, and engage in joint action in geographical locations or settings. The participants differed in the emphasis they placed on particular elements of the definition. Community was defined similarly but experienced differently by people with diverse backgrounds." Sustainable tourism in islands has to answer the question of how tourism investment, environmental protection and social quality preservation outcomes can provide stable profitable tourism in the long run (Graci and Dodds, 2010). To avoid the issues related to sustainable tourism concept, Community Based Sustainable Tourism (CBST) has been introduced in many parts of the world, including island destinations. Community-based tourism enables tourists to discover local habitats, wildlife, and celebrate and respect traditional cultures, rituals and wisdom. Local communities are known as the key stakeholders in leisure and tourism management. Tourism has to be managed with the help and interest of all stakeholders with a focus on local inhabitants (Guyer and Pollard, 1997). Graci and Dodds, (2010) identify 10 challenges of community-based sustainable tourism development in islands, including, limited physical and natural resources, short-term thinking and lack of planning, foreign ownership, lack of awareness about sustainability, lack of measurement, multiple stakeholders with conflicting interests, lack of skill and funding, corruption and bureaucracy, lack of infrastructure and climate change. In the following sections, three case studies are discussed, showing how these challenges have been overcome. Three selected case studies to describe Community Based Sustainable Tourism in Puerto Princesa as follows. 


\subsection{San Carlos Floating Restaurant}

San Carlos floating restaurant is a recently initiated project, with about 30 community members actively participating. This was formally started in 2012, although some activities had been conducted since 2000. San Carlos River flows to Honda Bay, starting near the bridge of the highway, in length of about 7 kilometres. Dr. Gerry Ortega initiated this project, after which ABS-CBN became involved. As a grant to initiate this activity, ABSCBN provided 500,00o Pesos to build two boats. This project has now become a cooperative. There are 372 hectares of mangroves found in the area, consisting of 20 different types, according to a study conducted in 200o. The community contracts traditional dance performers, who works as boatmen and tour guides. About three boatmen operate to carry tourists in each boat tour. The design of the boat also represents the environment. "Bata Bato" is the name of a bird and its shape has been taken as the design of the boat as shown on Figure 3. Tourists can enjoy a buffet lunch on the boat while enjoying the surrounding mangroves. Each tour is about 1.5 kilometres towards Honda Bay. One boat trip can accommodate 20 tourists. The tour costs 2,500 Pesos and lunch costs 500 Pesos per head. This buffet lunch includes fish, shrimps, chicken, vegetables and locally famous dishes made from locally available ingredients, as well as a welcome drink made with lemongrass.

Boatmen are well trained by the Red Cross to provide first aid and they act as lifeguards in an emergency. They are well trained experienced swimmers and also well-experienced fishermen. The community is getting continuous support from the city government. Palawan State University is involved in teaching about tourism services, food preparation, sanitation and mangrove interpretation. Average monthly income from the whole project is about 28,00o Pesos. A portion is deposited for the maintenance of the boat. They accommodated 86 tourists in January 2013, but only 12 in July 2012. This CBST activity is facing high cost as a challenge. For example, if a couple wants to enjoy a boat tour while enjoying lunch they have to pay 2500 Pesos for the tour and 1000 pesos for lunch. If 10 people join, they only have to pay 5,000 Pesos to enjoy the tour while having lunch. Marketing and promotion of this activity has been a continuous challenge. Another issue is lack of active participation of the community members.

Most of the community members who joined this CBST activity are farmers and fishermen. Still they continue farming and fishing because the income from this activity is not sufficient. Recently, they implemented a project on crab fattening. City Agricultural office gave 30,000 Pesos to initiate this project and also a three-day on-site special training. They provide know-how and supervision on crab fattening activities as an alternative livelihood program. San Carlos community has a plan to open a souvenir shop, which will sell local products, such as handcrafts, from bamboo. Participants have attended several training sessions and, as a result, their capacity has increased. City Tourism Office and Palawan State University conducted a series of training sessions. Income has increased, as has knowledge. Now they have a very clear understanding about hospitality and tourism. Community members send report every month to City Tourism Office. During an informal discussion, a local community member said, "100 hectares of mangroves are equal to a ton of fish." Mrs. Sol Ibrahim, secretary of the association, who is a high school graduate, said, "I am happy about this project in overall. I am a single mother with three kids. Though income is not enough, I still enjoy because I help local community by this activity."

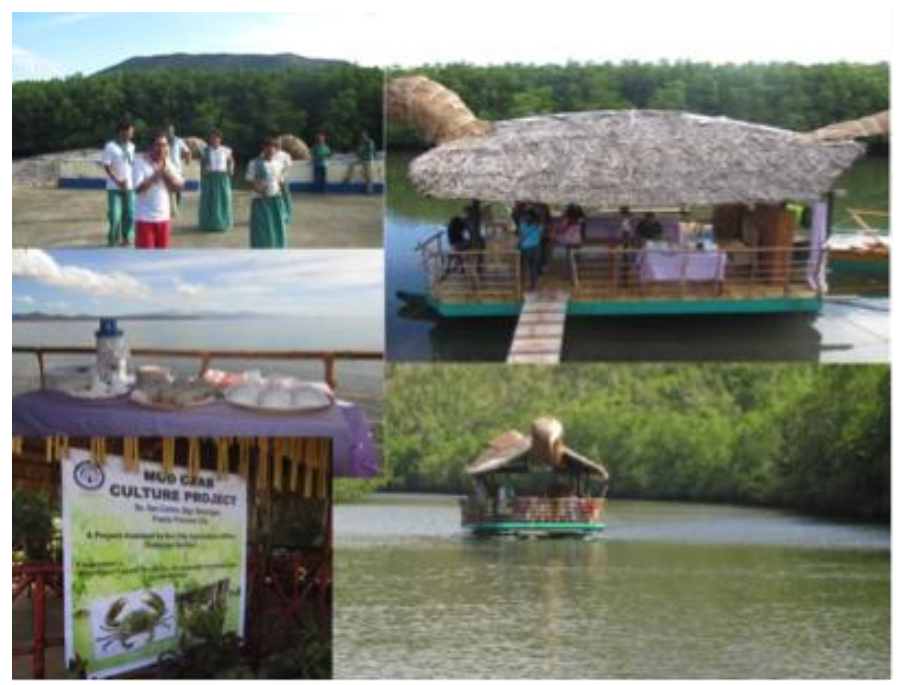

Figure 3 San Carlos Floating Restaurant (Source: Author 2013)

\subsection{Sabang Mangrove Paddleboat Tour}

Sabang Mangrove Tour is one of the fascinating attractions of Palawan. This project was initiated through the efforts of various NGOs and the city government in 2002. There are three to four boats in operation every day. Contribution from the partnering organizations was received only for three years. During this period, Sabang community has engaged in training, especially the scientific aspects in relation to mangroves. Tour guides, who also work as boatmen, received 15-day training, and each one of them is capable of communicating in English. During 2002 to 2008, there were not many visitors, sometimes only five visitors per week. But there has been an increase of visitors after 2008. In 2009, 10,000 tourists enjoyed paddleboat tours, and in 2010 the number increased to 15 ,ooo. Every tourist is asked to sign a record book before joining the tour. During the boat tour, the guide provides information about mangroves and they point out a variety of types. There are 15 tour guides who work in rotation. They have to be at least 18 years of age to become tour guides. The promotions about the project are done through pamphlets placed at hotels and in information centers at airport. Visitors can enjoy wildlife, the sounds of birds, and can see snakes on the branches of mangrove trees. The tour guide sings a song in the local language and also translates it to English, expressing the beauty and the importance of mangroves. After the boat tour, the visitors are welcome to plant mangrove trees as a memory to leave in Sabang. Bottom right of Figure 4 shows the author planting a mangrove after the boat tour in his initial field visit to Sabang in 2010.

The road to Sabang is of very low standard, and it is a muddy road on private land. This is one of the main reasons for the low number of tourists. This boat ride costs 100 Peso (\$2 - \$3 per visitor.) Also the visitors are welcome to provide donations. From this income, 20 percent is allocated to the protection of mangroves and barangay (village) development project. The remaining 80 percent is divided among tour guides. Also, financial support is provided for the local community when there is an emergency, illness or accident. In Sabang, the total mangrove area is only about four hectares, which is the natural forest. There are no activities of harvesting of mangrove trees for livelihood activities. 
Only the indigenous people are allowed to extract firewood, and the local community is now convincing them to use alternative options. In the fallen branches of mangrove, a worm can be found called 'Tamilo.' This is a local delicacy that people eat raw and warm, dipped in lime juice. Tourists can give donations and can try this very healthy local delicacy.

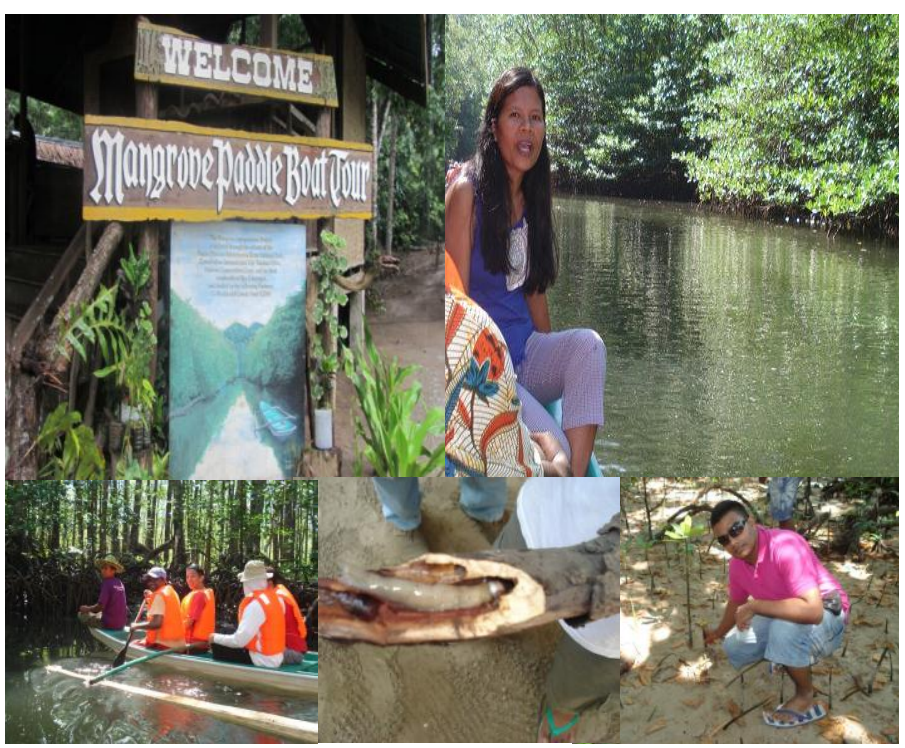

Figure 4 Sabang Mangrove Paddleboat Tour (Source: Author 2010, 2011 and Kumara 2010)

\subsection{Firefly Watch in Iwahig Mangrove Forest}

This project was initiated by ABS-CBN, which invested money and worked together with the city government. They didn't require any repayment, but in return the community was requested to protect nature. This project was started in 2008 and averagely 20 people from the local community worked per night. These members consist of 11 boatmen, three information staff, and community members who invite potential tourists. There are 137 members of ICETA (Iwahig Community Ecotourism Association) involved in this project. Most of the mangroves have been here for many years and cannot be cut down or harvested for any business. During the daytime and during off-season, boatmen and local community members gathers together and plant mangroves near the river. In 2010, there was a record of 7,032 visitors. Safety is guaranteed, and the boatmen are well trained as lifeguards in case of emergency. Safety jackets are provided as shown in Figure 5, and visitors can participate in small workshops or information sharing meetings using the poster presentation at the site.

Promotion of this activity is done through tourist hotels, travel agencies, and tricycle drivers through word of mouth. One boat tour costs 600 Peso (approximately $\$ 7$ ) and a boat accommodates three visitors. The boatmen are well educated and do the job of a tour guide while paddling the boat. The boatmen are also knowledgeable about the scientific, social and environmental aspects of the mangroves and fireflies. Out of total daily income, 50 percent is shared among the staff who worked that particular day and the remaining 50 percent is for the community organization. The local community can access that money as a loan in an emergency at a very low interest rate.

\section{Results}

A city with two UNESCO World Heritage Sites, Puerto Princesa City is providing a unique and impressive example of environmentally sound tourism in action (Graceffo, 2007). A study, conducted by the PCSD in 2005, with the support of JAFTA, is the most reliable updated data available to evaluate the mangrove forest cover in Puerto Princesa. This study showed that the current mangrove cover in Puerto Princesa is 5,896 hectares, compared to 4,052 hectares in 1992. There was a slight increase in mangroves in 1998 , compared to 2005. An official at PCSD noted that the study in 1998 was conducted by a private organization using a different mechanism. Therefore, it is difficult to make a comparison because the mechanisms were different in 1998 and 2005. However, compared to the 1992 data, it is clear that, in Puerto Princesa City, mangrove forest has increased during the last two decades, as shown in Figure 6. There was a positive growth of mangroves in the province of Palawan. It was just 29,910 hectares in 1992 and grew to 57,386 hectares by the year 2005 in Palawan province, as shown in Figure 7.

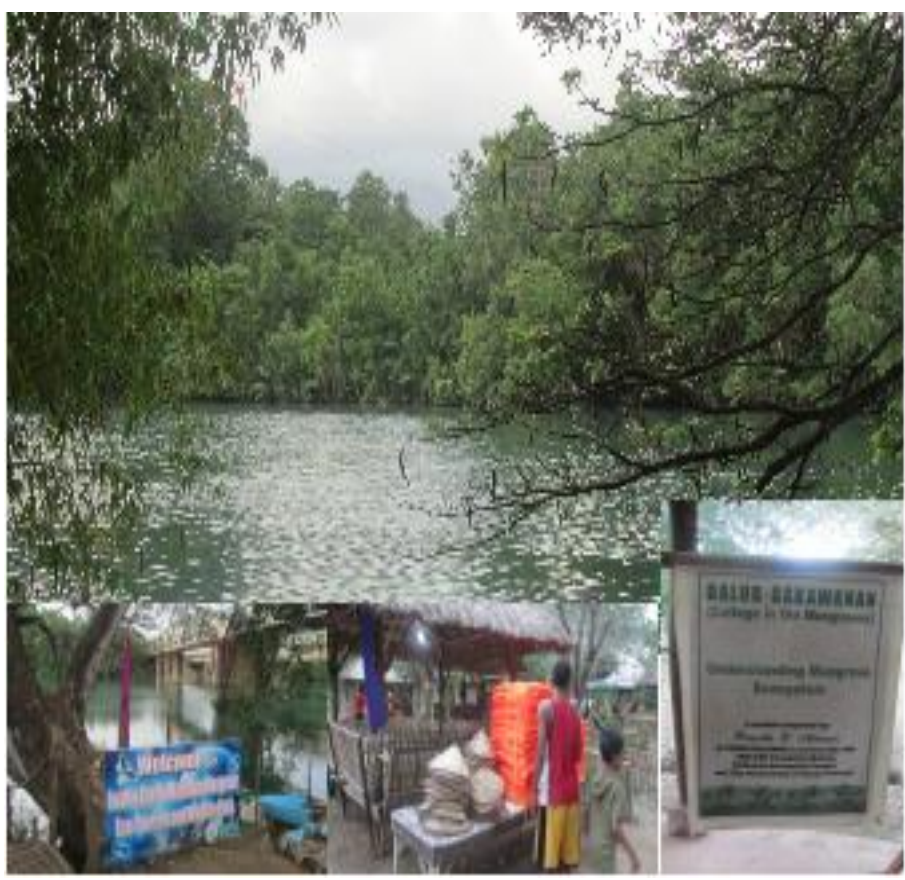

Figure 5 Iwahig River and Mangrove Surrounding (Source: Author 2011) 


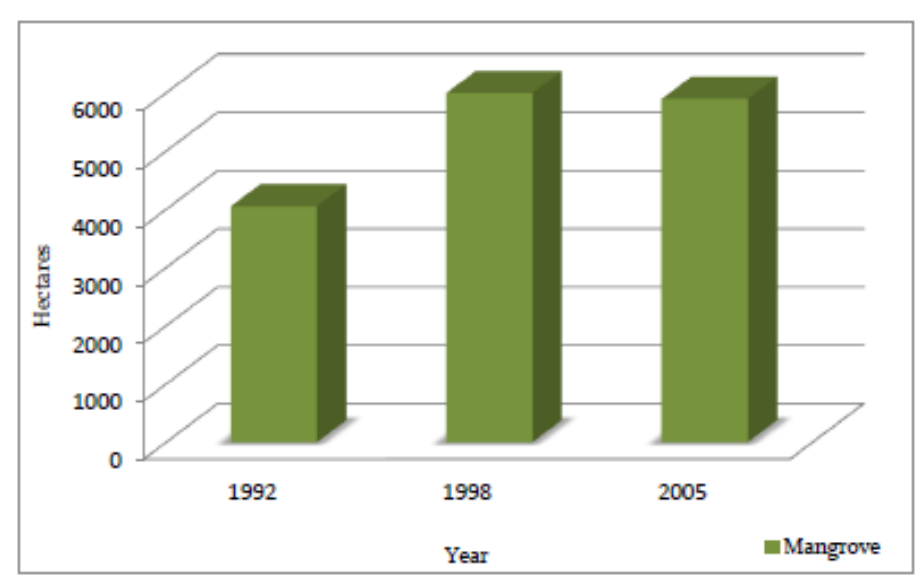

Figure 6 Mangrove Cover in Puerto Princesa (Source: PCSD, 2010)

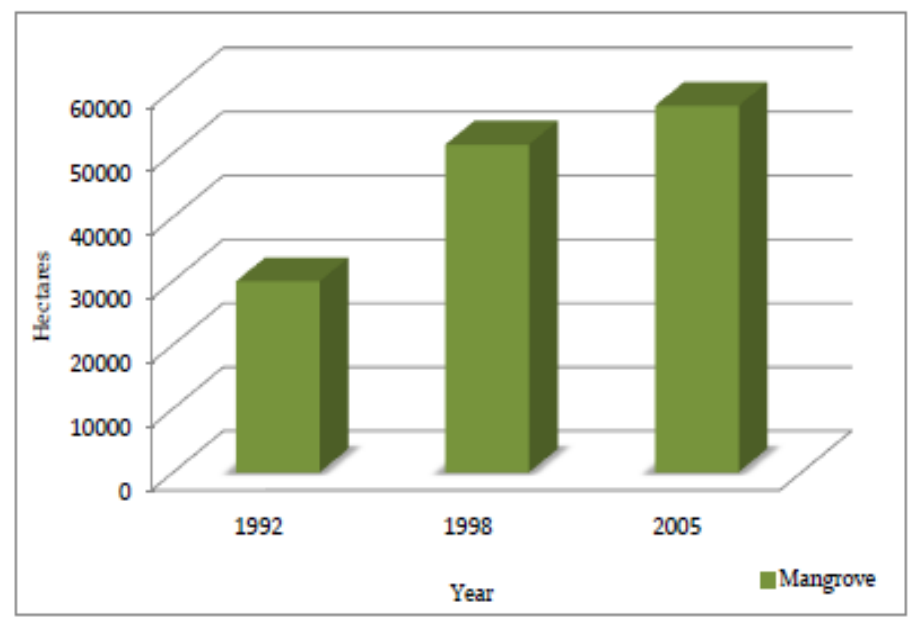

Figure 7 Mangroves in Palawan Province

(Source: PCSD, 2010)

There is clear evidence that mangrove forest cover in the world is declining. In the Philippines, this decline rate has been massive in the past few decades. In Palawan, however, there is one example that shows a different trend than the usual global trend. Citizens of Puerto Princesa are proud to be environmentally sound citizens. They strongly believe that more mangroves will be a habitat for more fish and fireflies and will result in more visitors and increased income. According to the Research and Development Extension Framework (2007 - 2010), the DENR does not allow permission for fishpond establishment in vegetated areas in order to conserve, protect, and develop the remaining mangrove resources of the Philippines. All these areas were placed under protected status to form part of the Integrated Protected Area System (IPAS). The increase of mangrove forest in Puerto Princesa is also backed by this kind of national policy.

\section{Discussion}

Based on literature mentioned earlier, Table 1 was prepared by the author to provide a comparative analysis of the three case studies to further emphasize the overcoming of common challenges of sustainable tourism in island destinations. Ten common challenges to island tourism are being discussed by Graci and Dodds in 2010. The comparative table 1, shows how above mentioned three cases have overcome them.

Apart from these tourist attractions, the annual "Love Affair with Nature" mangrove planting project is held on February $14^{\text {th }}$. As an attraction, a mass wedding was introduced, with planting a mangrove seedling the first thing that every couple does soon after their marriage. Sixty-four local community members provided feedback during interviews. They rated it as either "very important" or "important" to plant mangroves, community involvement in plantation, protection of planted mangrove forests, legal action against loggers of mangrove forests, managing stability of planting projects, and implementing similar projects in other islands of the Philippines and other countries. They gave various choices to only the question of "importance of payment for local community for protecting." However, none of them said it is not at all important to any of the statements, except for payments.

Before Mayor Hagedorn came to power, the city was filled with garbage. The mayor's first project was moving garbage and creating the first engineered sanitary landfill in the Philippines (Graceffo, 2007). Not only has the city's crime rate dropped closer to zero, but also people are busy with leisure and sports activities. The mayor has established 300 public Montessori schools and several medical centers to guarantee education and health for the local community. Tourism activities consistent with environment protection are integrated with other social development programs in the city. This integration, linking cleanliness, beautification, sanitation, save the sea, save the air, information and education, is known as "Oplan Linis Plan" (Graceffo, 2007).

Javelosa 2010 stated that "The story of Puerto Princesa Mayor Edward Hagedorn is common knowledge. Bad boy enters politics in 1992 for the first time in a place he didn't even grow up in. Bad boy turns around to transform first himself to follow an inner vision as he looked at a corrupted, polluted, dirty, poverty ridden backwater of a place. What his story, alongside that of Puerto Princesa's, the capital of the island of Palawan, has shown is the rise of the successful, progressive, visionary local leader with the passion and dedication towards the protection of the environment alongside countryside development". His passion, commitment and dedication have pushed the message from up to bottom and locals follow it. Environmental friendliness is "a way of life" for citizens in Puerto Princesa. In any development activity, the city mayor and officials keep the environment as the centerpiece in order to maintain their city as a "City in the Forest." 
Table 1 Overcoming Sustainable Tourism Challenges

\begin{tabular}{|c|c|c|c|}
\hline Challenge & San Carlos Floating Restaurant & $\begin{array}{l}\text { Sabang Mangrove } \\
\text { Paddleboat Tour }\end{array}$ & $\begin{array}{l}\text { Firefly Watch in Iwahig } \\
\text { Mangrove Forest }\end{array}$ \\
\hline $\begin{array}{l}\text { 1. Limited physical and } \\
\text { natural resources }\end{array}$ & Less resources needed & $\begin{array}{l}\text { Less resources needed and } \\
\text { mangrove area is comparatively } \\
\text { small }\end{array}$ & Less resources needed \\
\hline $\begin{array}{l}\text { 2. Short-term thinking and } \\
\text { lack of planning }\end{array}$ & $\begin{array}{l}\text { Planning needs to be more } \\
\text { focussed and several steps need } \\
\text { to be established to implement } \\
\text { other alternative livelihood } \\
\text { projects }\end{array}$ & $\begin{array}{l}\text { Well-planned except for } \\
\text { infrastructure development }\end{array}$ & Well-planned \\
\hline 3. Foreign ownership & Locally owned by the community & $\begin{array}{l}\text { Locally owned by the } \\
\text { community }\end{array}$ & Locally owned by the community \\
\hline 5. Lack of measurement & $\begin{array}{l}\text { Recently implemented and only } \\
\text { keeps a record of visitors and } \\
\text { monthly preparation of a report }\end{array}$ & $\begin{array}{l}\text { Monthly and annually prepared } \\
\text { reports being sent to the City } \\
\text { Tourism Office }\end{array}$ & $\begin{array}{l}\text { Monthly and annually prepared } \\
\text { reports being sent to the City } \\
\text { Tourism Office }\end{array}$ \\
\hline $\begin{array}{l}\text { 6. Multiple stakeholders } \\
\text { with conflicting interests }\end{array}$ & $\begin{array}{l}\text { Some participants are not active } \\
\text { and still think other options are } \\
\text { more financially viable }\end{array}$ & $\begin{array}{l}\text { Community is fully committed } \\
\text { but indigenous people are not } \\
\text { cooperating as expected }\end{array}$ & $\begin{array}{l}\text { Community is fully committed } \\
\text { and satisfied }\end{array}$ \\
\hline 7. Lack of skill and funding & $\begin{array}{l}\text { Receiving funds from city } \\
\text { agriculture and tourism offices to } \\
\text { further develop; current income } \\
\text { is not sufficient }\end{array}$ & $\begin{array}{l}\text { Income is increasing annually } \\
\text { and current staff members are } \\
\text { well-trained }\end{array}$ & $\begin{array}{l}\text { Income is increasing, training } \\
\text { going on but the staff is well- } \\
\text { trained }\end{array}$ \\
\hline 10. Climate change & $\begin{array}{l}\text { Continuing issue but community } \\
\text { is contributing to reverse the } \\
\text { global trend }\end{array}$ & $\begin{array}{l}\text { Continuing issue but } \\
\text { community is contributing to } \\
\text { reverse the global trend }\end{array}$ & $\begin{array}{l}\text { Continuing issue but community } \\
\text { is contributing to reverse the } \\
\text { global trend }\end{array}$ \\
\hline
\end{tabular}

Source: Author (2013) adapted from Graci and Dodds (2010)

\section{Conclusions}

Community-based mangrove related tourism, coupled with an annual mangrove planting project, shows such ingredients of sustainability as government involvement, necessary law enforcement, political will, proper leadership, community involvement, alternative livelihoods, education campaign, involvement of all local and national organizations, and willingness of local communities. Former Mayor Edward Hagedorn worked continuously during the last two decades, focusing on projects that support the environment, education and welfare in
Puerto Princesa. Various projects have been conducted in order to enhance the capacity of local citizens. They are fully aware of economic social and environmental benefits of these ongoing projects. Puerto Princesa City provides avery unique and impressive examples for mangrove forest rehabilitation and protection, in association with community-based sustainable tourism activities. For its commitments by leadership and community, Puerto Princesa City has won a variety of international awards. The city was recognized as the "Cleanest and the Greenest City" in the Philippines, including the achievement of becoming the first carbon neutral city of the ASEAN region. Figure 
8 provides clear evidence, as seen from the sky above Manila (Capital city of the Philippines) international airport and Puerto Princesa airport. The green sceneries of Puerto Princesa further show it to be a rich city with mangroves that is sustainably developing with a strong emphasis on its natural environment.
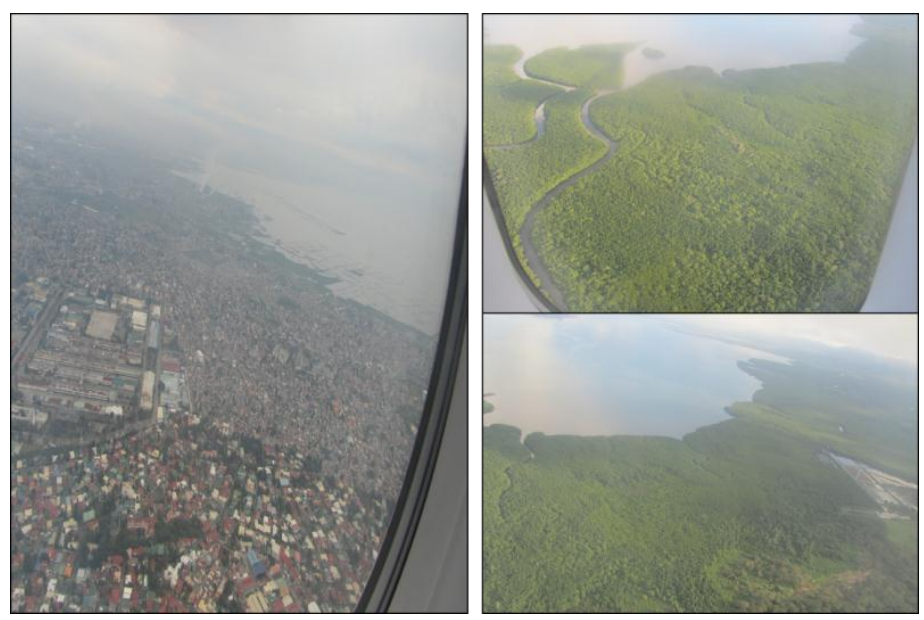

Figure 8 From Manila to Puerto Princesa (Source: Author 2011)

\section{Acknowledgements}

A special thanks to Dr. Ramon, Dr. Patrick of PSU, Former Mayor Edward Hagedorn, City Office staff, City ENRO staff, PCSD staff, and all local community members who provided support during field visits. Also, a special thanks to Dr. Sanga, Dr. Susumu, Dr. Fellizar and Dr. Miyoshi of APU for the continuous advice, all other staff members at APU for continuous support and Professor Faulkner for the help provided in editing this research paper. Also a warm thank to Kobayashi International Scholarship Foundation for providing a scholarship to conduct research and studies.

\section{References}

[1] City Information Office. "Socio Economic and Economic Profile", internal communaication document, Puerto Princesa City; 2007.

[2] Mark Spalding, Mami Kainuma, Lorna Collins. World Atlas of Mangroves, Eaerthscan publications; 2010.

[3] Melana, D. M. Mangrove Management Handbook. Manila: Coastal Resource Management Project of the Department of Environment and Natural Resources; 2000.

[4] Maltby, E. Waterlogged Wealth: Why Waste the World's Wet Places? London: Earthscan Publications; 1986.

[5] Mangrove Action Project (MAP). Tourism. http://mangroveactionproject.org/issues/tourism; 2013

[6] Kelleher, G., Bleakley, C. and Wells, S. A Global Representative System of Marine Protected Areas. Volume 1. Great Barrier Reef Marine Park Authority, The World Bank and World Conservation Union; 1995.

[7] FAO (Food and Agriculture Organization) Global Forest Resources Assessment 2005: Progress Towards Sustainable Forest Management. Rome, Forestry Department. FAO; 2006.

[8] Barbier, E.B. Habitat-Fishery Linkages and Mangrove Loss in Thailand. Contemporary Economic Policy, forthcoming;2003.

[9] Anderson, J.L. and Fong, S.W. Aquaculture and International Trade. Aquaculture Economics and Management 1(1); 1997

[10] Naylor, R.L., Goldburg, R.J., Primavera J.H., Kautsky, N., Beveridge, M.C.M., Clay, J., Folke C., Lubchenco, J., Mooney, H. \& Troell, M. Effect of aquaculture on world fish supplies. Nature 405; 2000 1017-1024.

[11] Duke, N.C., Meynecke, O.J., Dittmann, S., Ellison, A.M., Anger, K., Berger, U. Cannic, S., Eiele,K., Ewel, K.C., Field, C.D., Kodedam, N.,
Lee, S.Y., Marchand, C, Nordhanus, L., and Dahdough-Guebas, A world without mangroves? www. Sciencemag.org; 2007. p41.

[12] Valiela, I. J.L. Bowen and J.K. York Mangrove Forests: One of the World's Threatened Major Tropical Environments. BioScience; 2001. 51(10), 807-815.

[13] Department of Environment and Natural Resources DENR. intervies with officials using internally used documents; 2011.

[14] Cheryl Joy J. Fernandez, Rodelio F. Subade and Paul Erwen T. Parreño. 8th National Symposium in Marine Science held in Palawan State University, Puerto Princesa City on October 20-22, 2005.

[15] Department of Environment and Natural Resources (DENR). 2003. Forest Management Bureau. http://forestry.denr.gov.ph/reqcbfma.htm. accessed 8th September 2013.

[16] Primavera, J.H. Development and Conservation of Philippines Mangroves: Institutional issues, Ecological Economics, vol 35; 2000. p91

[17] Fernandez, P.M. Regulations and their impact on mangrove areas for aquaculture - the Philippine experience. Workshop Proceeding on the conversion of mangrove areas to aquaculture, Iloilo, 1978. pp. 78-84

[18] Research and Development and Extension (RDE) Framework on Environment and Natural Resources 2007 - 2010. College, Laguna: DENR-ERDB. 2007. P39, P43, $62-65$

[19] Gracy S., Dodds R. Sustainable tourism in Island Destinations, Earthscan, London; 2010.

[20]Dimitrios Stylidis, Matina Terzidou, Konstantinos Terzidis. Island tourism and its socio economic impacts. http://mibes.teilar.gr/proceedings/2007/poster/StylidisTerzides\%2oM-Terzidis\%2oK.pdf; 2007. accessed on $10^{\text {th }}$ June 2013.

[21] Dodds, R. And McElroy, J. St Kitts at a crossroads', ARA journal of travel Research; 2008. 1(2): 1-10

[22] Lockhart, D.G. Islands and tourism: an overview. In: D.G. Lockhart and D. Drakakis- Smith (eds) Island Tourism, - Trends and perspectives. London: Pinter; 1997. pp 3-21

[23] Butler, R.W. Tourism - an evolutionary perspective. In: Nelson, J. G.; Butler, R.; Wall, G. (eds.). Tourism and sustainable development: monitoring, planning, managing: 27-43. Waterloo: University of Waterloo; 1993 .

[24] World Tourism Organization (WTO) UNEP and UNWTO. Making Tourism More Sustainable - A Guide for Policy Makers; 2005.

[25] Kathleen M. MacQueen, Eleanor McLellan, David S. Metzger, Susan Kegeles, Ronald P. Strauss, Roseanne Scotti, Lynn Blanchard, and Robert T. Trotter. What Is Community? An Evidence-Based Definition for Participatory Public Health. American Journal of Public Health: December; 2001 Vol. 91, No. 12, pp. 1929-1938.

[26] Guyer, C., Pollard, J. Cruise visitor impressions of the environment of the Shannon-Erne waterways system. Journal of Environmental Management;1997. 51, 199-215.

[27] Graceffo A. Puerto Princesa: The Philippines' Cleanest and Greenest City wildasia.org. http://www.wildasia.org/main.cfm/RTI/Puerto_Princesa; 2007.

[28] Palawan Council for Sustainable Development (PCSD), intervies with officials using internally used documents; 2010, 2011, 2013.

[29]Javelosa Jeannie E. Feast of the forest Philstar.com http://www.philstar.com/allure/593897/feast-forest; 2010

[30] City Environment Office. "Love Affair with Nature”, internal communaication document, Puerto Princesa City; 2011.

[31] Kathiresan, K. and Bingham B. L. Biology of mangrove and mangrove ecosystems. Advances in Marine Biology; 2001. 40.

[32] Spalding, M., Blasco, F. and Field, C. World Mangrove Atlas. International Society for Mangrove Ecology, World Conservation Monitoring Centre; 1997.

[33] World Resources Institute (WRI). World Resources 1996-7. World Resources Institute. New York: Oxford University Press; 1996. 